\section{ROBERT WIGHT (1796-1872), DR. FREKE AND THE "ORIGIN OF SPECIES"}

\author{
By T. E. T. BOND \\ Tea Research Institute of Ceylon
}

$\mathrm{A}^{\mathrm{N}}$ $\mathrm{N}$ interesting sidelight on the Darwinian controversies of the early 1860's is afforded by some fragments of contemporary correspondence which have recently come to my notice and which are worth placing on record as much for their subject as for their intrinsic merit of style. The documents accompanied some volumes of Robert Wight's Indian botanical works - the "Illustrations of Indian Botany" and autographed copies of the "Spicilegium Neilgherrense" and vol. 6 of the "Icones Plantarum . .."-generously loaned to the library of this Institute by his greatgrandson, Mr. H. C. Cosens, who is a Ceylon tea planter. They consist of four draft letters in Wight's handwriting addressed to Dr. Freke, of Dublin, on the subject of two pamphlets by the latter author which are also preserved with the letters. Freke is largely concerned with establishing the priority of his own yiews over others which he attributes to Darwin; Wight, in his letters, has some trenchant observations of his own to make as to the relative merits of the conclusions reached by these two authors. I have no means at present of finding out whether the final version of the letter was ever sent or, if sent, whether it is still in existence; nor have I the opportunity of following up many of the points of historical and biographical interest which are raised by this material. In this article I shall not attempt to do more than briefly introduce the two characters concerned and thereafter, so far as possible, allow the papers to speak for themselves.

Robert Wight left India in 1853 , so that all his botanical works while in that country might be expected to have a 'pre-Darwinian' flavour.' As anyone who is in the least acquainted with them will know, they are indelibly stamped with his own forceful and vigorous personality in addition. The blending of the age and the man is seen nowhere to better advantage than in his preface to the "Spicilegium Neilgherrense", written, presumably, in 1846. A follower, for practical purposes, of the de Candollean modifications of Jussieu's system, he here enlarges on the desirability of attaining to a still closer approximation of "the true Natural System of Botanical classification, now so ardently sought for by all philosophical Botanists". $\mathrm{He}_{e}$ is indeed well aware of the di.nculties in the way, not the least of which is that, as he says, ". . . even the most learned and philosophical among them, seem not to know quite clearly what they are in search of and of course can scarcely be expected to inform others what they do not well understand themselves".

Having disposed of the argument that the natural system "is neither more nor less than a human contrivance", and demonstrated that there can only be one such, namely, that which repeats the design of the Creator, he proceeds to show that the "Circular method" affords the best clue to its discovery. The system that is favoured presupposes a ternary, or rather quinary, subdivision of the animal and vegetable kingdoms by analogy with the three primary circles of affinity, namely, "Animals being the typical circle, Vegetables the sub-Typical and Inanimate matter the Aberrant; which last is made up of three minor ones the endless modifications of Earth, Water and Air; each equally perfect, thus making together a series of five". All is well so far as the first stage in the subdivision whereby, for example, the exogens (or dicotyledons) are revealed as analogous with the vertebrates. Afterwards, however, "the Zoological system ... seems to have gone far ahead of the Botanical" and even in the latest systems of Lindley and of Endlicher, which are briefly noted, no satisfactory quinary subdivision is attained for the primary exogenous and endogenous groups. To make good this deficiency, Wight then sketches out a provisional quinary classification of his own, using many of the Lindley and Endlicher class names. His groups, he says, "have a circular appearance and give promise that ... their thorough investigation may put us on the right path and speedily enable us to reach the long and anxiously sought for goal". For Wight, "to discover these [circles], if they actually exist in Nature, appears in the present state of enquiry to be the first and grand desideratum towards the discovery of the true Natural System of plants".

While Wight was speculating on the logical advantages of the one true natural system of classification as revealing the orderly plan of the Creator, Freke was developing a system whereby the actual process of creation could have been effected. His ideas in the main appear to have been derived from Bichat (1771-1802), who postulated "that the life of the body is the outcome of the combined lives of the constituent tissues" (Sir William Dampier, "A History of Science", 3rd edn., p. 274). For these tissues, Freke infers an ultimate common origin in a primordial form, the "embryo of organic creation". He thus claims to be the original propounder of the doctrine of descent and stoutly maintains that it is he, and not Darwin, to whom credit for this doctrine should be given. In a short paragraph devoted to Freke in the historical introduction to the revised edition of the "Origin of Species", Darwin refers (p. 19) to "the dificult attempt to give any idea of his views" ; indeed, not without reason, as will be demonstrated in the ensuing paragraphs.

Freke's earlier pamphlet is evidently a reprint of the circular mentioned by Darwin (loc. cit.), which was published originally in October 1860. It consists largely of quotations from the author's articles in the Dublin Medical Press of the years 185i-52, and in its present edition takes the form of a prospectus for his book "On the Origin of Species by Means of Organic Affinity", newly published in 1861. The title is an obvious counter to Darwin's work to which, he says, surely with studied under-emphasis, "My attention has, within the last few days, been directed by the merest accident . . - -a work, which as I have been given to understand, is at the present moment attracting a large share of public attention". His position is soon defined; following the review (presumably Bishop Wilberforce's) in the Quarterly, and with entire neglect of the principle of natural selection and the arguments upon which it is based, he quotes Darwin's statement that "Analogy would lead to the belief that all animals and plants have descended from some one prototype" as the sole point at issue. $\mathrm{He}$ "feel[s] it to be due, as well to myself as to science, to acquaint the physiological public that although that theory has now been reached through a different channel, it has not now been announced for the first time. Nine years before the appearance of Mr. Darwin's publication, I, as the 
result exclusively of inductive inquiry, submitted this identical hypothesis to the judgment of physiologists -a conclusion which Mr. Darwin has since attained to by analogy".

The original announcement of the theory is sup. ported by the first of the quotations from the Dublin Medical Press of November 1851. In this, Freke presents as an important subject of physiological inquiry the distinction between the organic world "at the period of its creation" and at "its present advanced stage of development". The second paragraph of the quotation is worth reproducing in full, with Freke's italics and parentheses:

"The line of investigation which (as it appears to me) should be pursued in such inquiry is the followingnamely, I should endeavour to ascertain,-first, what is the constitution of organic creation as it now exists; or in other words, what is the constitution of the present generation of organised being? and secondly, how or in what manner has the present generation been generated or formed by the preceding generation? A knowledge of these two facts would (as I conceive) furnish us with data from which to collect a certain amount of information as regards the necessary constitution of the origin or (if I may venture to term it) of the embryo of all generations. For if the manner in which organised beings universally have been generated can be accurately traced back for one generation, there is nothing to prevent its being, with equal accuracy, traced back for many; and the possibility is that it may, with a certain degree of accuracy, be traced back for all generations; that is, in other words, till we have eventually arrived, in imagination, at (if I may so term it) the embryo of Arx organic creation".

Pursuing this inductive inquiry on the assumption that all individual living beings "have been formed by the union of a number of minute organisms", or "organizing atoms", he reaches the conclusion (at first sight almost a foreshadowing of the discovery of the linear arrangement of genes in the chromosome) that the "embryo of organic creation" consisted of "a chain composed of perhaps but a few individual microscopic granules".

Later in the same article, the nature of this chain of organizing atoms is further defined. Each atom is to be regarded as a "distinct species of organizing matter", with the common function, however, of indefinite' self-regeneration through the process of imparting ever higher degrees of organization to the "organized residual products" of the atom beneath it in the chain, the lowest atom of all having as its substratum of activity "the unorganized or mineral world". The various "organizing atoms", by uniting in various ways, were supposed to constitute the "first or earliest embryos" of different plant and animal species, their "organized residual products" similarly combining to form "the various compound residual products required by Nature to enable those embryos to discharge their physiological function". "This, I say, appears to me to have been the origin of species by means of what I have ventured to term organic affinity". Freke is no believer in evolution in the Darwinian sense: he is concerned merely with the formation of "the first generation of living beings", not with any possibility of their subsequent modification by descent. Indeed, he is at pains to emphasize, beneath the title of his book, that "Nothing is advanced in this publication that is not perfectly in harmony with the Mosaic record of Creation".

So far, it is not difficult for the modern reader to find in Freke's "organizing atoms" and their products an analogy with his own concepts of genes, organiza. tion centres, etc.; but the author soon makes it clear that he has in mind categories of much more limited anatomical signifieance only. This is developed in the postscript to the above quotations and especially in the second of the two pamphlets, which is dated October 1862 .

The heading of the second pamphlet (considerably shortened) runs :

"TABULAR VIEW of the relation... between the Three Kingdoms of Nature with regard to Organization; including that subsisting between Organizing Agents and Organized Residual Products ...., shewing at the same time the Circle of the same elementary components ....; and pointing to the nature of the dependency of LIFE upon DEATH in both the Vegetable and the Animal Kingdom",

The pamphlet chiefly adds the names of the "organizing atoms"-lignat, musculat, celebrat, otc., with, rather surprisingly, georgat as the first of the vegetable series - "the simple germ (or atom) which organizes earth". Finally, the dependence of life upon death is illustrated by considering the difference between the plant and animal worlds, the "organic life" of plants involving merely the death (and simultaneous regeneration) of organizing agents, the higher form of "animal life" involving in addition a second species of death, namely the death of the organized residual products. As evidenoe of this, the indefinite increase in size of the plant body is contrasted with the fixed size of the animal. The views expressed in this second pamphlet are traced in part to an essay published in 1848 ("Freke on Organization"), in part to the article, already referred to, in the Dublin Medical Press of 1852.

Reading Freke's pamphlets, one cannot help but admire his apparent ingenuity and fertility of imagination, even while exasperated and amused in turn by the redundancy of his style. It is not for me to assess the originality of his ideas; but at least it is surprising to find him omitted from the "Dictionary of National Biography". Here, only "John Freke (1688-1756), surgeon" and "William Freke (16621744), mystical writer", find a place; and either, one feels, would have been an appropriate forbear.

That Robert Wight, no less than Darwin, found it difficult to deal with Freke's views is apparent from his manuscripts, which can now be described. The letters were written in Wight's retirement, presum. ably from Grazely Lodge, Berkshire, and from the internal evidence they can be dated to within the first fortnight or so of December 1862. Three out of the four can fairly easily be arranged in order : the first (about three hundred words, in pencil on the back of a seedsman's circular) is apparently a rough draft for the second (about 550 words) which, in turn, was expanded into the third (about a thousand words), written a week later. Of these, I propose to give extracts, making, so far as possible, a continuous narrative, the references in brackets (1-3) indicating the source of the material as described above. The fourth, which is unfortunately a fragment only (about three hundred words, on a half sheet of paper, apparently with a preceding portion torn away) is less easy to place; being in addition rather lighter and more personal in style as compared with the others, it may be quoted, almost in its entirety, as a fitting tailpiece to the series.

In the opening paragraph of (2) and (3) there is a reference to some earlier criticisms made by Wight, apparently well received. These perhaps related to the pamphlet(s), Wight being presented afterwards with copies of the author's books; as mentioned in the letter : 


\begin{abstract}
"My Deer Gir;
"I win binmed to have to begin my letter with the obarfoesion that at least 10 days have elapsed since I had the plemsure of receiving your letter of the 22nd and the books which arrived the dey after. I accept them with many [thanks] and hope we shall some future day have the pleasure of becoming better acquainted. I was exceedingly pleased to learn that my criticisms were so well received for, to tell you the honest truth, I was very fearful, when I read over for the last time what I had written, that on some points I had been much too severe and thought of either suppressing my letter altogether rather than hurt your feelings further after the strain to which they had already been put, or write the whole over. The latter alternative was out of the question so I determined to send it on, hoping for the best. Since happily you think the critieism was not really unjust and was written in a really friendly spirit let us bury the objectionable parts in the saying that 'tis all well that ends well'.

"Since the receipt of your volumes I have been reflecting a good deal on your and Mr. Darwin's views on the origin of species and right or wrong have arrived at a conclusion somewhat different from both. You say you have arrived at a conchusion 'as the result exclusively of inductive enquiry' which Mr. Darwin has since attained to by Analogy. In this statement I think you have fallen into an error. To my mind, induction is the process employed in both cases, with this difference, that the inductive process begins at opposite ends. He reasons backwards from the perfect plant and animal to the primordial germ, whereas you reason from the assumed germ onwards to the perfect animal. He says 'I cannot doubt that the theory of descent with modifieation embraces all the members of the same class. I believe that animals have descended from at most four or five progenitors and plants from an equal or lesser number'. That is the theory arrived at by induction. He then adds that analogy would lead one one step further, namely to the belief that all animals and plants have descended from one prototype: and adds that analogy may be a 'deceitful guide'; then winds up by saying that he would infer from analogy that probably all organic beings that ever lived have descended from one primordial form into which LIFE was breathed by the Creator. His theory, then, rests on a persevering close induction carried on through 480 pages; the finale only is an Analogical inference. And that inference I think questionable.
\end{abstract}

"You, on the other hand, assume that the Creator imparted life to a germ which then went on multiplying itself and your induction, resting on that assumption, goes to show that such must be the case. The induction therefore, every step of which may be unquestionable, rests on a postulate which you can't prove. Darwin's, on the other hand, rests in the first instance on unquestionable facts, the known tendency of both plants and animals to form variations" (3).

Although the logic of Darwin's argument is thus favourably contrasted with Freke's, his conclusions are not thereby rendered acceptable. This is well brought out by reference to an earlier version, namely :

"Darwin being a laborious painstaking man and a deep very eautious thinker started on his course of investigation, which for twenty years he has never ceased to follow up, from certain undeniable data of every day occurrence among both Animals and Vegetables, their liability namely under certain circumstances to variation. Then, calling in the aid and experience of the breeder and gardener and allowing unlimited time he has as he supposes traced back organization to a point or at most a few points or monads or primordial germs ox any other name you may prefer but still admits that these germ or germs must in the first instance have derived its vitality from a higher [? source]. Working on that idea for 20 or more years he has ransacked every source of information which he can directly or indirectly bring to bear on the subject and has made a very interesting book, heavy at times to read

*A quotation conveniently omitted by Freke. from his peculiar style, but to my mind lost labour for it leads to nothing, does not advance our knowledge of the origin of vitality and only claims for it powers which all our experience goes to disprove. . . ." (1).

A big stumbling-block is the apparent fixity of living species and the difficulty of envisaging modifcations of the size demanded by the evolution theory. As Darwin puts it ..." "we are always slow in admitting great changes of which we do not see the steps".

"A grain of pollen the 100,000th part of an inch in diameter is placed in contact with the pistil of its own species and a great tree results; but apply the pollen of an Oak to the Alder or Pine or any other genus but its own and it fails to impregnate the ovum. This law holds throughout the whole vegetable kingdom ...

"From this I infer that the Deity in creating organic germs, supposing that was his mode of proceeding, imparted to each its specific character, which, with some modification, it still retains; by which it is permitted to vary within certain limits. The Gardener produces floral varieties in any number but he can't change an apple into a pear nor a cherry into a plumb [sic]. The pigeon breeder ean by selection and careful breeding obtain many varieties among the species of that genus but can't change a pigeon into a hawk, and won't the same law hold good through the whole of the organic kingdom? Specific variations are everywhere observable, but not transitions from one natural order or genus to another (2)

"It is difficult if not quite impossible with almost any streteh of the imagination, assisted even by myriads of years, to faney such an unit as a Byssus becoming a lofty Palm, or a monocotyledonous grass an umbrageous oak" (3).

But the biggest difficulty of all, in accepting either theory, is the philosophical one: the element of chance is felt to play too great a part. Wight, as much as Freke, ignores completely the force of natural selection.

"Since reading Darwin's volume, I have thought much of his theory as summed up in the concluding page and with every wish to view it with a favourable eye I cannot bring [my] mind to accept it as a correct exposition of the Creator's plan in covering the earth [with] its organic inhabitants, vegetable and animal. We can in imagination conceive the deity imparting to certain atomic elements the force called life, enabling them to impart the same force to others of the same kind just as a spark falling among suitable materials will raise a great fire, but I cannot accept the idea that out of such materials- shapeless vitalized atoms- the wonderfully complex organisations each and all possessing the most perfect adaptation to its wants could ever have been derived without the aid and guidance [of] omnipotent power and inscrutable wisdom. From the first promulgation of the idea as deduced from Analogy my question has always been, what does Philosophy gain by its adoption? The aid of the Deity is required to set life in motion, why then limit his power to the mere giving of life, leaving it to circumstances to determine its forming a shapeless puffball or a man ? (2).

"... having required the aid of Omnipotence to organize our first atom it behoves us to return to the same source and solicit inscrutable wisdom to superadd those laws of eombination and arrangement which we find pre. vailing throughout organic existence. . . I go a step further and add that since the aid of the Deity is needed in the first instance to impart life and organisation, that organic philosophy gains nothing whatever-it may lose -by adopting the doctrine [of] the creation of a solitary primordial form-germ or atom, call it what you willand leaving all the rest to secondary causes" (3).

To Wight then, 'organic philosophy' carried the day and the evolutionists were found wanting. The order and logic of the natural system with its quinary circles of affinity were perhaps more to his liking than 
the ruthlessness of natural selection and the fmprobabilities of the "embryo of AEt organic ereation". But at least the issue was not decided without much thought. Of all the four versions of the final verdict which have survived in these manuscripts, none is more characteristic than that which follows, in conclusion :

". . . But I now find that were I to attempt extending my notes on the subject they would form quite an essay ..., while my imperfect acquaintance with the science of the present day would to some extent disqualify them for publication in tre state they flowed from my pen. As mere suggestions to help a master mind they might perhaps be useful, but scarcely otherwise. But be that as it may, I am not by any means satisfied in my own mind that either of you have attained the desired goal though you attempt to reach it by such different routes. He [i.e. Darwin] starts from the present time and by a rigid process of induction argues that nature commenced her existirig animal kingdom by the creation of some 4 or 5 forms, her vegetable one by about as many primary vegetable forms thousands of years ago. Such is the process by which the patient and laborious Saxon go'es to work. The rapid thinking and impulsive Celt on the other hand, having caught sight of his theory in the distance, straightway bounds to prove by induction that it must be right. While the cautious Scotchman looks first at the one and then at the other and right or wrong thinks both have missed the mark and concludes that Moses is the profoundest Philosopher of the three since he is content to take things as he finds them and in one word declares all we know or are ever likely to know by saying God Created, without enquiring how".

\section{STRUCTURE AND EVOLUTION OF THE LEVANT AND NORTHERN AFRICA}

\author{
By DR. K. S. SANDFORD \\ University Museum, Oxford
}

$\mathrm{T}$ HE following notes are an attempt to recapitulate the essential stages in the development of the southern side of the western Tethys and of the Mediterranean. They refer particularly to Leo Picard's publications, especially "Structure and Evolution of Palestine, with Comparative Notes on Neighbouring Countries"*, from the point of view of the geologist who has some familiarity with north African problems. Much that is still in doubt and much of local significance must inevitably be omitted; nevertheless a broad review of this type may be useful at the present juncture.

At the end of the Pre-Cambrian, Palestine lay on the borders of a high (Upper Algonkian) mountain range in which earlier mountains and varied rock types were welded into a mountain mass: this may be traced from Arabia through Sinai and the Red Sea Hills into Africa ("Arabo-Nubian mass"). PrePalæozoic denudation reduced the mountains to a lowland with seas lying on the west and north, the latter being identified with an east-west Palæozoic sea. Marine Cambrian beds are recorded on the mainland mass of north-west Africa and of western Asia, and from the Cambrian to the Cenozoic there were farreaching transgressions across Mauritania, the Sahara,

* Structure and Evolution of Palestine: with Comparative Notes on Neighbouring Countries. By Leo Picard. (Bulletin of the Geological Department, Vol. 4, Nos. $2,3,4$.$) Pp. iv +134. (Jerusalem$ Geological Department, Hebrew University, 1943.)
Libya and Egypt into the interior of Africa, across Palestine into Arabia.

Durïng regresisive phases, widespread continental beds were laid down over areas formerly marine. As there was continuous subaerial denudation and accumulation over the land areas, stratigraphy there is concerned largely with the interdigitation of continuous and discontinuous subaerial deposits, lagoonal and marine beds. The shore-line, continually shifting, was frequently indented: the sea and its lagoons ran far into deep bays between promontories on which subaerial processes continued. The advances of the epicontinental seas might therefore be called, as Picard suggests, ingressions rather than transgressions. The major promontories were broadly related to swells or structural undulations, the locations of which in northerm Africa are plainly marked.

The continental beds consist for the most part of dune-sands and fluviatile quartz conglomerates : similar beds are now accumulating in the continental interiors of Arabia and northern Africa. Nubian Sandstone is an unfortunate term for these beds, in my opinion; Nubian facies expresses all that is desired : Nubia (in a broad sense) and lands to the south of it have probably been continental since the Pre-Cambrian.

Palæozoic transgressions (or ingressions) occurred in Palestine and adjoining territories in the Middle Cambrian, Ordovician, Silurian, Lower Devonian (?) and Lower Carboniferous (Sinai and on the Egyptian side of the Gulf of Suez) : the Silurian left graptolitebearing shales in Central Arabia.

In northern Africa the Palæozoic transgressions, Cambrian, Ordovician, Silurian, Lower-Upper Devonian, Lower Carboniferous seem to have come from the west rather than the north. The Silurian graptolite-bearing shales can be traced far into the interior, where they pass into sandstones. In w'estern Asia, as in northern Africa, the Carboniferous seems to have witnessed final Palæozoic regression. The Triassic palæography of Palestine was nevertheless related to that of the Palæozoic, with a shelf sea, transgressive from the nearly Tethys, in the Lower-Middle Trias, followed by Upper Triassic uplift and continental beds.

The north-western corner of the African shield, with its Palæozoic blankets, was involved in Hercyn. ean mountain building, and Triassic (or PermoTriassic) red beds with salt mark a stage in the ensuing denudation: except for small patches of lagoonal beds, the unfolded continental platform seems to be devoid of Triassic rocks.

In Sinai and Palestine there was renewed transgression of a Jurassic sea shallowing eastward: locally there are thick Bajocian-Kimmeridgian beds following a Lower Jurassic (Liassic) continental phase. Moreover, the uppermost Jurassic (Portlandian) beds appear to be regressive-continental, a condition which was maintained until Wealden (Lebanon - Palestine), Albian (Syria), or Cenomanian (Eastern Sinai-Transjordan) transgression supervened. The 'facies of the Nubian Sandstone' predominated during the regressive and transgressive phases; there was extensive volcanic activity and probably fracture in the transition from the Jurassic to the Cretaceous.

There is a small exposire of marine Jurassic beds on the Egyptian gide of the Gulf of Suez; otherwise they do not seem to be exposed in Egypt, Libya or the Sahara : some continental beds are known in Libya, and probably there are others. A new element is discernible however, namely, the Mesozoic sea of 